\title{
Genetic Structure and Variability of Natural Populations of Maritime Pine (Pinus pinaster Aiton) in Morocco
}

\author{
By N. WAhid ${ }^{1,3}$, S. C. GonzÁlez-MARTínez ${ }^{2}$, I. El HAdRAmi ${ }^{3}$ and A. Boulli ${ }^{1, *}$
}

(Received $16^{\text {th }}$ December 2003)

\begin{abstract}
The estimation of genetic diversity using molecular markers is a major component of genetic conservation programs. In its range, Maritime pine has been extensively studied using different molecular markers and quantitative traits. However, Moroccan populations have been usually represented only by a few typical locations in the Middle Atlas (e.g., Tamjout). To describe the genetic structure and variability of maritime pine in Morocco, eleven populations of this species comprising all major geographic regions (Rif, Middle Atlas and High Atlas) were studied using allozyme markers. A total of 471 samples were analyzed using polyacrylamide gel electrophoresis (PAGE) of eight enzyme systems encoded by 19 loci. Genetic variation was lower in Morocco than in other ranges of the species. However, genetic diversity was structured and a high differentiation among populations $(\theta=10.44 \%)$ and a moderate correlation between genetic and geographic distances were found (0.350). Three main groups of populations can be distinguished based on genetic distances: (i) Mediterranean Coastal, (ii) Occidental Rif and Middle Atlas and (iii) High Atlas. The populations from Middle Atlas presented the lowest values of allelic richness and gene diversity whereas the populations from Rif showed a considerable amount of genetic variability. Human impact and isolation are major factors explaining population genetic structure of maritime pine in Morocco. Overexploitation of the forest by intensive cattle grazing and land speculation are suggested to be active mechanisms currently deploying the genetic resources of this species.
\end{abstract}

Key words: Pinus pinaster, genetic structure, genetic diversity, genetic conservation, allozymes, Morocco, maritime pine.

\section{Introduction}

The distribution of genetic variation among and within populations is a major concern in plant population genetics. The presence of natural genetic variation is a key factor for the adaptation of forest trees to environmental changes. The scenarios for global climatic warming in the Mediterranean region foresee an important increase of temperatures in the next decades $\left(\sim 4.5^{\circ} \mathrm{C}\right.$ by 2050$)$ and changes in the amount of precipitation as high as a $50 \%$ with respect to the rainfall over the last 30 years (Hulme 1999). Marginal populations (i.e. those growing at the edges of their range or those restricted to singular environments) might contain original gene complexes and trees adapted to growing in extreme environments or showing disease or pest resistance, thus providing valuable base material for current and future breeding programs of forest trees

1) Laboratoire d'Analyse et de Valorisation des Ressources Environnementales, Département des Sciences de la Vie, Université Cadi Ayyad, Faculté des Sciences et Technique, BP 523, Béni-Mellal, Maroc.

2) Unidad de Genética Forestal, CIFOR-INIA, P.O. Box 8111, 28080 Madrid, Spain.

3) Laboratoire de Physiologie Végétale, Département de Biologie, Université Cadi Ayyad, Faculté des Sciences Semlalia, BP 2390, 40000 Marrakech, Maroc. E-mail: hadrami@ucam.ac.ma

*) Abdelali Boulli, Phone: +212 23485112 , Fax: +212 23485201. Email: a.boulli@fstbm.ac.ma
(HARFouche et al., 1995, 2000; NGUYEN-QUEYRENS et al., 1995). Moreover, the conservation and management of genetic diversity are integral parts of forest planning (RAFFIN, 1999; SAVOLAINEN, 2000) and can influence forest management decisions, such as the selection of the cutting regime. However, the absence of basic information on diversity and genetic structure in many tree species and the restriction of the available studies to particular ranges limit the development of effective policies for the conservation and use of forest genetic resources (ROGERS and LEDIG, 1996). Range-wide surveys of genetic diversity based on genetic markers can be useful to provide basic decision tools and to define forest-planning policies (e.g., PEтiт et al., 1998).

Isozyme analysis has been used over the past two decades to investigate the population genetic structure of a large number of organisms, from fruit flies and wild herbs to humans (Nevo, 1978). In forest trees, isozyme markers have been largely used to assess genetic diversity (HAMricK and GodT, 1990; MüLlERSTARCK et al., 1992). Reviews on isozyme variation of plants have disclosed that conifers are one of the most variable groups of plant species and that the populations of most of the species store high levels of genetic variability (HAMRICK et al., 1979; LOVELESS and HAMRICK, 1984). This variability is generally attributed to the open wind-pollinated monoecious reproductive system, the long life-cycles and the distribution in large continuous populations of most conifer species.

Maritime pine (Pinus pinaster Aiton) is a conifer native to the western part of the Mediterranean basin, including continental France and Corsica, the Iberian Peninsula (Spain and Portugal), Italy (including Pantelleria island) and northwestern Africa (Morocco, Algeria and Tunisia). Recent studies based on mtDNA-RFLP analysis have identified three maternal lineages in maritime pine (BURBAN and PETIT, 2003). The eastern mtDNA lineage is distributed in northeastern Spain (only one population, located at Catalonia), southeastern France, Corsica, Italy (including Pantelleria Island), Tunisia and Algeria. The western mtDNA lineage includes populations found in the remaining Iberian Peninsula, continental France and Punta Cires (northern Morocco). The Moroccan lineage is specific of Morocco. Different maternal lineages in maritime pine may represent different isolated glacial refugia of the species. Several lines of arguments have lead to the hypothesis that the quaternary glaciations have played a major role in the genetic structuring of maritime pine (BARADAT and MARPEAU, 1988; SALVADOR et al., 2000; CARRIón et al., 2000). In addition, a recent review of molecular marker (allozymes, chloroplast and nuclear microsatellites and amplified fragment length polymorphisms) and quantitative trait (i.e., common garden experiments) studies showed that a differentiation of the three maternal lineages can still be found using these different kind of chloroplastic and nuclear genome traits (GONZÁLEZ-MARTínEZ et al., 2004 and references therein).

In Morocco, maritime pine is a frequent tree species and an important natural resource in terms of both economic benefit and land protection. Nowadays, this species covers approximately 12000.00 hectares and, although it is not widespread, 
it is found in most forested regions: the High Atlas, the Middle Atlas, the Rif and the Mediterranean coastal region. It is the second species used in term of reforestation and its range covers an extremely wide variety of soil types and climatic conditions. The present-day size of native populations varies considerably (26-286 ha), though never reaching the big extensions of continuous forest of other ranges such as Portugal or Central Spain (DestremaU et al., 1976). The population size of Moroccan maritime pine forests, though reflecting general factors related to their ecology, is often linked to human impact. The comparison of forest inventories conducted in 1976 (DESTREMAU et al., 1976) and 1997 (Deutsche Gesellschaft für Technische Zusammenarbeit and Ministère de l'Agriculture, Administration des Eaux et Forêts, Royaume du Maroc) showed the disappearance of some populations along the Moroccan range of maritime pine. Surviving stands are characterized by their fragility, instability and frequent degradation. Human population growth has led to overexploitation and accelerated degradation of forest resources. In the north, along the Mediterranean coast, fires, land speculation and uncontrolled recreational activities are having serious repercussion in the preservation of maritime pine stands, recently becoming a matter of concern for both government and general public (M'HIRIT, 1999). Recently, a general interest in the preservation of forest resources have aroused changes in Moroccan forest policy that require managers to introduce alternative reforestation systems into maritime pine plantations and limit genetic erosion to provide greater structural diversity and so enhance aesthetic conservation and environmental benefits (M'HIRIT and MAGHNOUJ, 1994; M'HIRIT et al., 1997).

Moroccan populations of maritime pine may represent a unique genetic resource. However, genetic sampling of this region has been generally poor and based on a few populations (typically Tamjout and in some cases Tamrabta, both located at the Middle Atlas). Only one single study has exclusively focused on Moroccan populations of maritime pine. EL-AlAMI et al. (1997) studied the enzymatic polymorphism in five native Moroccan populations using starch gel electrophoresis of isozyme systems encoded by seven loci. Taking base on preliminary results, EL-ALAMI et al. (1997) reported no clear evidence of population genetic structure or differences in genetic diversity among populations. The limited sample size of this study highlights the necessity of more extensive ones.

Accordingly, the aim of this study is to analyze population genetic structure and variability in 11 natural populations of maritime pine (Pinus pinaster Aiton), covering the range of the species in Morocco. Spatial analysis and information about the distribution of gene diversity among populations will complete the picture already available on other ranges of the species. Recommendations about the management of forest genetic resources of maritime pine in Morocco are also provided.

\section{Materials and Methods}

\section{Plant material}

Samples of maritime pine were collected from 11 natural populations in Morocco (Figure 1 and Table 1). Trees sampled were randomly chosen at least $50 \mathrm{~m}$ apart from each other along North-South transects following climatic gradients materialized by the altitude and the exposure. Extracted Seedlots were placed in Petri dishes on top of filter paper disks moistened with distilled water. The seeds were incubated at $25^{\circ} \mathrm{C} / 17^{\circ} \mathrm{C}$ day/night, with $16 \mathrm{~h} / 8 \mathrm{~h}$ light/darkness regime (15000.00 lux). Seeds were considered for enzyme extraction when showing a small radicula. An average of 41 (36 48) germinated seeds were analyzed separately to detect isoenzyme poly-

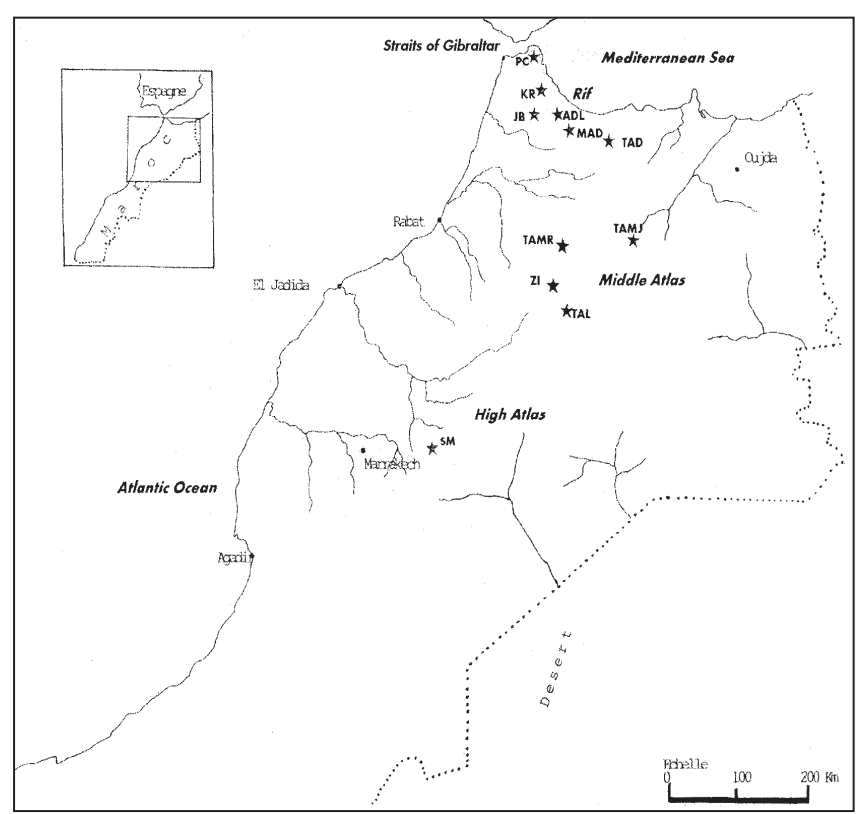

Figure 1. - Location map of 11 native maritime pine populations sampled in this study.

Table 1. - Location, stand area and climatic parameters of 11 native populations of maritime pine in Morocco. Tmax and Tmin stand for mean maximum temperature and mean minimum temperature, respectively.

\begin{tabular}{|c|c|c|c|c|c|c|c|c|c|}
\hline Code & $\begin{array}{l}\text { Population } \\
\text { name }\end{array}$ & Region & Longitude & Latitude & $\begin{array}{c}\text { Altitude } \\
\text { (masl) }\end{array}$ & $\begin{array}{l}\text { Size } \\
\text { (ha) }\end{array}$ & $\begin{array}{c}\text { Rainfall } \\
(\mathrm{mm})\end{array}$ & $\begin{array}{l}\operatorname{Tmax} \\
\left({ }^{\circ} \mathrm{C}\right)\end{array}$ & $\begin{array}{l}\text { Tmin } \\
\left({ }^{\circ} \mathbf{C}\right)\end{array}$ \\
\hline PC & Punta cires & Rif & $35^{\circ} 55^{\prime} \mathrm{N}$ & $5^{\circ} 28^{\prime} \mathrm{W}$ & 40 & $175-25$ & 709 & 29.5 & 10.8 \\
\hline $\mathrm{KR}$ & $\begin{array}{l}\text { Koudiat } \\
\text { Erramla }\end{array}$ & Rif & $35^{\circ} 28^{\prime} \mathrm{N}$ & $5^{\circ} 23^{\prime} \mathrm{W}$ & 400 & 140 & 699 & 33.5 & 5.5 \\
\hline$J B$ & $\begin{array}{c}\text { Jbel } \\
\text { Bouhacheme }\end{array}$ & Rif & $35^{\circ} 14^{\prime} \mathrm{N}$ & $5^{\circ} 25^{\prime} \mathrm{W}$ & 1094 & 95 & 2168 & 28 & $0-3$ \\
\hline ADL & Adeldhal & Rif & $35^{\circ} 08^{\prime} \mathrm{N}$ & $5^{\circ} 09^{\prime} \mathrm{W}$ & 1450 & 168 & 1490 & 30 & $2.7-4$ \\
\hline MAD & Madisouka & Rif & $35^{\circ} 11^{\prime} \mathrm{N}$ & $5^{\circ} 10^{\prime} \mathrm{W}$ & 1880 & 168 & 1483 & 31.9 & 2.3 \\
\hline TAD & Tadiwine & Rif & $34^{\circ} 56^{\prime} \mathrm{N}$ & $4^{\circ} 32^{\prime} \mathrm{W}$ & 1520 & 172 & 1501 & 21.6 & 0.5 \\
\hline TAM & Tamjout & $\begin{array}{l}\text { Middle } \\
\text { Atlas }\end{array}$ & $33^{\circ} 50^{\prime} \mathrm{N}$ & $3^{\circ} 59^{\prime} \mathrm{W}$ & 1550 & 130 & 422 & 37 & 4.2 \\
\hline TAL & Talaghine & $\begin{array}{l}\text { Middle } \\
\text { Atlas }\end{array}$ & $32^{\circ} 27^{\prime} \mathrm{N}$ & $5^{\circ} 14^{\prime} \mathrm{W}$ & 1840 & 20 & 362 & - & - \\
\hline TAMR & Tamrabta & $\begin{array}{l}\text { Middle } \\
\text { Atlas }\end{array}$ & $33^{\circ} 36^{\prime} \mathrm{N}$ & $5^{\circ} 01^{\prime} \mathrm{W}$ & 1760 & 270 & 763 & 34 & $<-2$ \\
\hline ZI & Zaouia Ifrane & $\begin{array}{l}\text { Middle } \\
\text { Atlas }\end{array}$ & $33^{\circ} 13^{\prime} \mathrm{N}$ & $5^{\circ} 36^{\prime} \mathrm{W}$ & 1510 & 250 & 753 & 31.5 & 0.5 \\
\hline SM & Sidi Meskour & $\begin{array}{l}\text { High } \\
\text { Atlas }\end{array}$ & $31^{\circ} 28^{\prime} \mathrm{N}$ & $6^{\circ} 50^{\prime} \mathrm{W}$ & 1910 & 96 & 556 & - & $<-2$ \\
\hline
\end{tabular}

morphism (a total of 451 seeds). As total seeds (megagametophytes + embryos) were used for enzyme extraction, we obtained multilocus diploid genotypes for each seed.

\section{Isozyme analysis}

Newly germinated seeds were placed individually in $0.4 \mathrm{ml}$ of extraction buffer ( $1.6 \%$ Tris, $0.04 \%$ bovine serum albumin, $0.4 \%$ polyvinylpyrrolidone, $2 \%$ polyethylene-glycol, $0.05 \%$ dithiothreitol, $15 \%$ glycerol, and $1 \%$ ß-mercaptoethanol) at $\mathrm{pH}=7.2$. Seeds were homogenized by hand using a chilled pestle and mortar. Homogenates were centrifuged at $20000.00 \mathrm{~g}$ and $2{ }^{\circ} \mathrm{C}$, and the clear supernatants were stored for 2 to 4 days at $-20^{\circ} \mathrm{C}$ until used for electrophoresis.

Polyacrylamide gel electrophoresis (10\%) of the following eight enzyme systems was conducted: glutamate-oxaloacetate transaminase (Got; EC. 2.6.1.1), isocitrate dehydrogenase (Idh; E.C. 1.1.1.42), leucine aminopeptidase (Lap; E.C.3.4.11.1), alanine aminopeptidase (Aap; E.C.3.4.11.1), 6-phosphogluconic 
dehydrogenase (6Pgd; E.C.1.1.1.44), phosphoglucomutase (Pgm; E.C.2.7.5.1), phosphoglucoisomerase (Pgi; E.C.5.3.1.9) and shikimate dehydrogenase ( $S k d$; E.C.1.1.1.25). A total of 19 isozyme loci were resolved. Vertical electrophoresis was carried out at a constant voltage of $200 \mathrm{~V}(50 \mathrm{~mA})$ using a Tris-Glycine buffer. The separation of isozyme products was achieved after 2-3 hours of electrophoresis at $4^{\circ} \mathrm{C}$. For each enzyme system, the loci were sequentially numbered from the most cathodal to the most anodal. Recipes for the extraction buffer, isozyme staining and polyacrylamide gels can be found elsewhere (Conkle et al., 1982; Cheliak and Pitel, 1984; Kephart, 1990; RоTHE, 1994).

Table 2. - Allelic richness, genetic diversity (only polymorphic loci considered), and coefficient of inbreeding within populations, $f$, in P. pinaster populations from Morocco.

\begin{tabular}{|c|c|c|c|c|c|}
\hline Code & $\begin{array}{l}\text { Allelic } \\
\text { richness }\end{array}$ & $P(\%)$ & $\mathrm{He}$ & Ho & $f$ (Low95, Up95) $^{a}$ \\
\hline \multicolumn{6}{|l|}{ Rif } \\
\hline PC & 26 & 27.78 & 0.315 & 0.282 & $0.104(-0.184,0.579)$ \\
\hline $\mathrm{KR}$ & 26 & 27.78 & 0.367 & 0.292 & $0.207(0.093,0.547)$ \\
\hline JB & 27 & 33.33 & 0.364 & 0.292 & $0.200(0.108,0.407)$ \\
\hline $\mathrm{ADL}$ & 27 & 33.33 & 0.395 & 0.338 & $0.147(-0.080,0.379)$ \\
\hline MAD & 27 & 33.33 & 0.411 & 0.343 & $0.169(0.063,0.306)$ \\
\hline TAD & 27 & 33.33 & 0.371 & 0.259 & $0.304(0.063,0.669)$ \\
\hline Mean & $\begin{array}{c}26.67 \\
(S D: 0.52)\end{array}$ & $\begin{array}{c}31.48 \\
(S D: 2.87)\end{array}$ & $\begin{array}{c}0.371 \\
(S D: 0.033)\end{array}$ & $\begin{array}{c}0.301 \\
(S D: 0.033)\end{array}$ & $0.190(0.018,0.450)$ \\
\hline \multicolumn{6}{|l|}{ Middle Atlas } \\
\hline TAMJ & 26 & 27.78 & 0.362 & 0.380 & $-0.048(-0.207,0.249)$ \\
\hline TAL & 24 & 22.22 & 0.337 & 0.347 & $-0.031(-0.335,0.150)$ \\
\hline TAMR & 25 & 27.78 & 0.251 & 0.241 & $0.040(-0.234,0.382)$ \\
\hline ZI & 24 & 16.67 & 0.298 & 0.306 & $-0.027(-0.452,0.199)$ \\
\hline Mean & $\begin{array}{c}24.75 \\
(S D: 0.96)\end{array}$ & $\begin{array}{c}23.61 \\
(S D: 5.32)\end{array}$ & $\begin{array}{c}0.312 \\
(S D: 0.048)\end{array}$ & $\begin{array}{c}0.318 \\
(S D: 0.060)\end{array}$ & $-0.021(-0.232,0.192)$ \\
\hline \multicolumn{6}{|l|}{ High Atlas } \\
\hline SM & 27 & 33.33 & 0.332 & 0.333 & $-0.004(-0.281,0.431)$ \\
\hline Mean & 27.00 & 33.33 & 0.332 & 0.333 & $-0.004(-0.281,0.431)$ \\
\hline Grand mean & $\begin{array}{c}26.00 \\
(S D: 1.18)\end{array}$ & $\begin{array}{l}28.79 \\
(S D: 5.45)\end{array}$ & $\begin{array}{c}0.346 \\
(S D: 0.046)\end{array}$ & $\begin{array}{c}0.310 \\
(S D=0.042)\end{array}$ & $0.104(-0.075,0.365)$ \\
\hline
\end{tabular}

a Low95 and Up95 are the lower and upper 95\% confidence interval, respectively, computed using bootstrap re-sampling over loci $(1,000$ bootstraps).

\section{Genetic analysis}

Interpretation of zymograms (see Table 2) was done based on all populations studied and previous work by SALVADOR et al. (2000) and GonZÁLEZ-MARTínEZ et al. (2001). Only polymorphic loci with unambiguous patterns were retained and individual multilocus genotypes were obtained for the calculation of genetic parameters. Genetic variability was described by the following parameters: percentage of polymorphic loci $(P)$, allelic richness $(A)$ and the observed and expected heterozygosity $(H$ and $H_{e}$, respectively). Expected heterozygosity was calculated following NEI (NEI, 1973). Allelic richness, i.e. the number of alleles found in a given population, is highly dependent on effective population size and is more sensitive to past demographic changes than average heterozygosity, being a useful measure in conservation genetics (NEI et al., 1975; PETIT et al., 1998). The contribution of single populations to global genetic diversity and allelic richness has been analyzed following Pетіт et al. (1998). This method allows to distinguish between two components: the contribution due to the population's own diversity/allelic richness and the contribution due to its divergence from the diversity/allelic composition of the rest of the populations. When contributions to allelic richness were calculated, the rarefaction method of HURLBERT (1971) was used to cope with uneven population sample sizes. Population genetic structure was investigated using $F$-statistics as estimated by WEIR (1990). Confidence intervals for $F$-statistics were computed by bootstrapping 1,000 times over loci. NEI's unbiased genetic distance $(d)$ was also computed and a dendrogram was constructed using the UPGMA method. In addition, a Mantel test between genetic and geographic distances was done.

All analysis were conducted using PopGene ver. 1.31 (YeH et al., 1997), GenePop ver. 3.4. (RAYMOND and Rousset, 1995), Contrib (RÉmy J. Petit, INRA, Bordeaux) and GDA ver. 1.0. (LEWIS and ZAYKIN, 2001).

\section{Results}

A total of 471 samples from 11 populations were successfully analyzed using eight isozyme systems encoded by 19 loci. Twelve loci (6Pgd-1, 6Pgd-2, Got-1, Got-2, Got-3, Got-4, Idh-1, Skd-2, Aap-1, Pgm-2, Pgi-1 and Pgi-3) were consistently monomorphic in all populations, producing considerably low estimates of the number of polymorphic loci at population level (average of $28.78 \%$ ). Locus Pgi-2 was excluded from genetic analysis because it was not satisfactorily resolved in some populations. Zymograms for the six remaining polymorphic loci (Skd-1, Aap-2, Aap-3, Lap-1, Lap-2 and Pgm-1) are given in Figure 2.
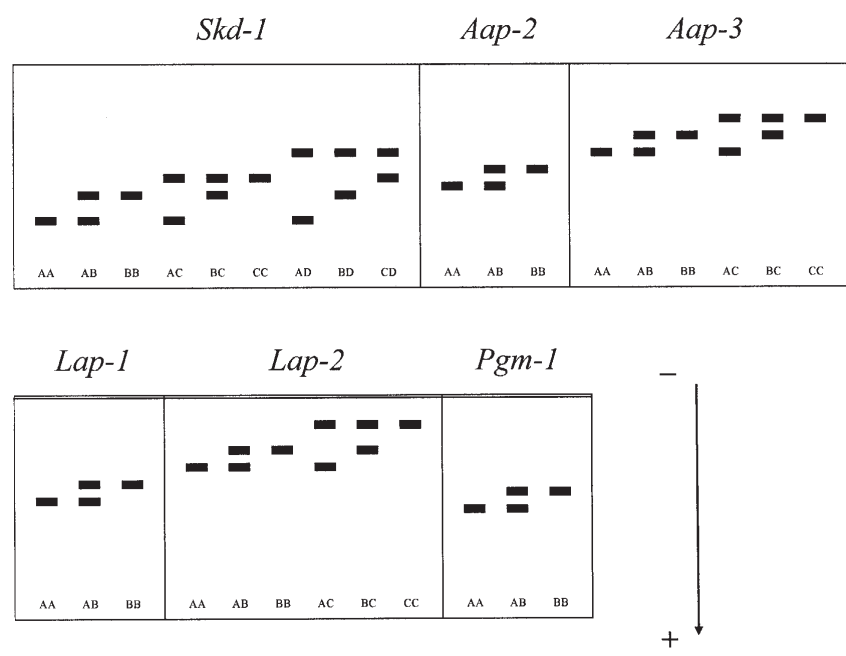

Figure 2. - Observed allozyme products and interpretation for $S k d$, Aap, Lap and Pgm systems encoded by six loci showing polymorphism in Moroccan native populations of maritime pine.

A total number of 28 alleles (average of 1.56 alleles per locus) has been found in native Moroccan populations of maritime pine. Only one population, Punta Cires (PC), showed a private allele (Skd-1, allele 4). Two other alleles (Aap-2, allele 1; and Lap-1, allele 2) were absent from three out of four populations analyzed in Middle Atlas (respectively, Talaghine, Tamrabta and Zaouia Ifrane, and Talaghine, Tamjout and Zaouia Ifrane). Allelic richness, genetic variability for polymorphic loci and inbreeding coefficients $(f)$ are presented in Table 2 . The populations from Middle Atlas showed less allelic richness than populations from Rif or High Atlas. In particular, Talaghine (TAL) and Zaouia Ifrane (ZI), both located in Middle Atlas, had the lowest number of alleles (24). The contribution of individual populations to total allelic richness is low, except for Punta Cires population, that contributes a $3.17 \%$, based mostly on a divergence component (Figure 3, top).

Genetic diversity estimates $\left(H_{e}\right)$ were also lower for Middle Atlas populations. In this case, Tamrabta (TAMR) showed the 

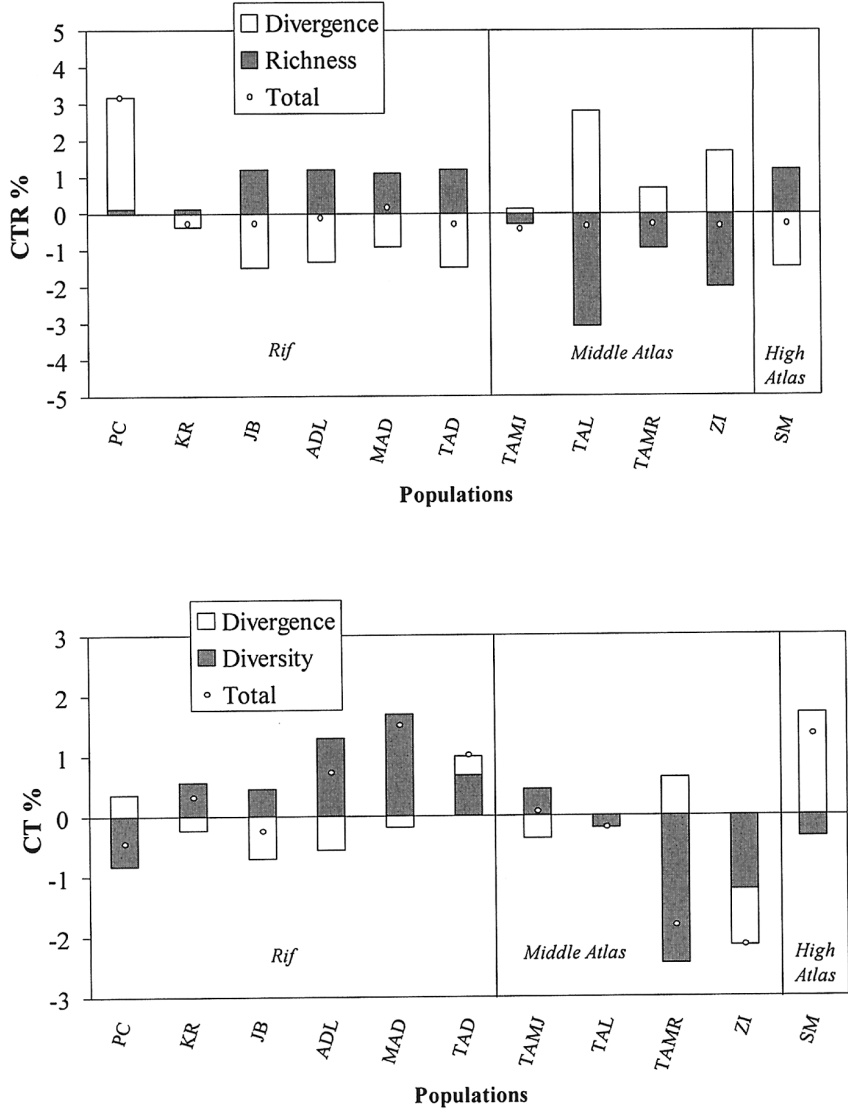

Figure 3. - Contributions of individual populations to total allelic richness (top), and to total genetic diversity (bottom) of 11 maritime pine populations. The contribution of each population is partitioned in two components: the contribution due to its own diversity/richness, and the contribution due to its divergence from the rest of populations.

lowest value (0.251). The highest values of diversity were found in Adeldhal (ADL, 0.395) and Madisouka (MAD, 0.411), both in the Rif region. Genetic diversity was intermediate at Sidi Meskour (SM, 0.332), the only population analyzed from High Atlas. A clear pattern of individual contributions to total genetic diversity was also present (Figure 3, bottom): most populations from Rif contributed positively to total genetic diversity whereas most populations from Middle Atlas had negative contributions. Sidi Meskour had an important contribution to total genetic diversity, $1.33 \%$, mostly based in its divergence from the rest of the populations. Remarkably, the inbreeding coefficient was significantly higher than zero in most of Rif's populations (four out of six) with an average of 0.190 .

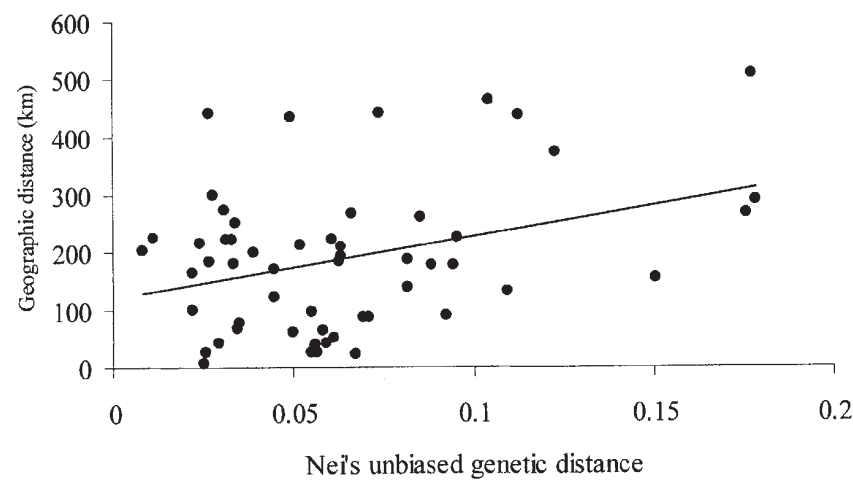

Figure 4. - Correlation between Nei's unbiased genetic distance and geographic distance. A linear trend line is also shown.
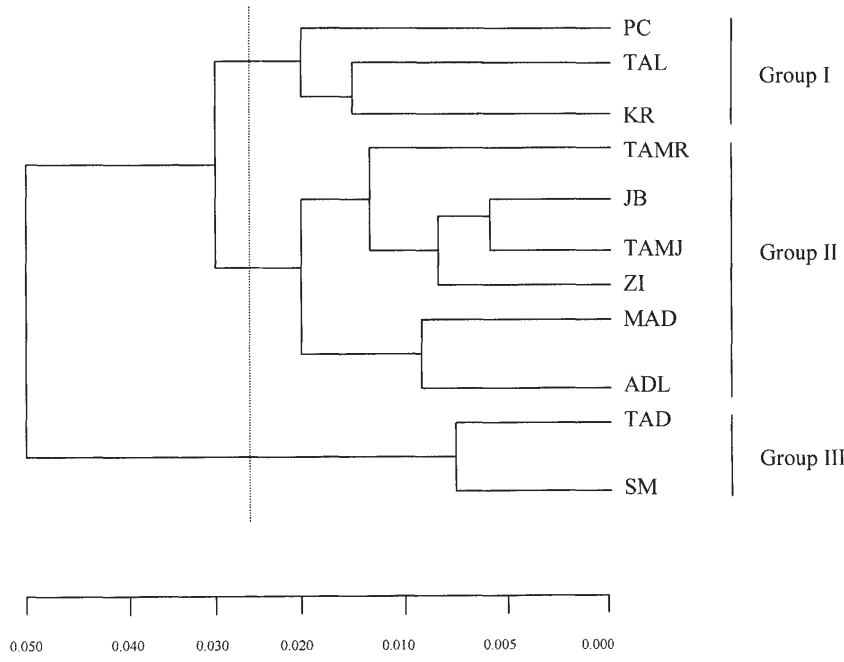

Figure 5. - UPGMA phylogenetic tree based on Nei's unbiased genetic distance for 11 native populations of maritime pine in Morocco.

Genetic differentiation is high in Moroccan maritime pine populations. Partitioning of variation within and among-populations using $F$-statistics showed a $\theta$ value of 0.1044 , significantly different from zero as shown by a bootstrapping procedure (95\% CI: 0.0729, 0.1384). Interpopulation differentiation is clearly found at loci Aap-3, Lap-1 and Lap-2. Moreover, genetic and geographic distances are correlated in maritime pine populations from Morocco (Figure 4). This correlation is marginally significant as shown by a Mantel test $(r=0.350, p=$ 0.085 ). Figure 5 shows an UPGMA phylogenetic tree based on NEI's unbiased genetic distance. The maximum (0.045) and minimum (0.003) pair wise genetic distances $(d)$ were found between Tamrabta (Middle Atlas) and Sidi Meskour (High Atlas), and Tamjout (Middle Atlas) and Jbel Bouhacheme (Occidental Rif), respectively. At the level of genetic distance, $d$, of 0.026 three groups can be differentiated. One cluster comprises populations from Mediterranean Coastal (Punta Cires and Koudiat Erramla) together with a population from Middle Atlas (Talaghine). The second cluster includes the populations from Occidental Rif (Jbel Bouhacheme, Madisouka, and Adeldhal) and the rest of the populations from Middle Atlas (Tamrabta, Tamjout, and Zaouia Ifrane). This cluster is further subdivided differentiating Madisouka and Adeldhal populations, both located in Occidental Rif, from the rest. Finally, a third cluster including one population from Occidental Rif (Tadouine) and the only population from High Atlas, Sidi Meskour, was present. Only populations Tadouine from Occidental Rif and Talaghine from Middle Atlas were clearly integrated in groups not corresponding with their geographic location.

\section{Discussion}

Surveys of genetic variation in maritime pine have been conducted in the last few decades using different kind of markers and traits (see review in GonZÁLEZ-MARTínEZ et al., 2004). Despite the importance of the Moroccan range of the species, sampling in this region has been incomplete and typically represented by just a few populations located at Middle Atlas, such as Tamjout and only a single study has focused exclusively in this distribution range (EL-ALAMI et al., 1997).

Electrophoretic variation in Morocco is lower than in other ranges of the species. The average number of polymorphic loci in our study was half that found in the Iberian Peninsula $(28.79 \%$ and $58.80 \%$, respectively; SALVADOR et al., 2000) and 
one population, Zaouia Ifrane, had a value of $16.67 \%$, much lower than the minimum value ever found in the Iberian Peninsula $(40.00 \%$ in the marginal population of Las Gabarras, northeastern Spain; our unpublished data). This happens even when the technique used in this study (PAGE) is more suitable than conventional starch gel procedures for the separation of complex associations of multiple forms of enzymes such as those of non-specific enzyme systems (GotTLIEB, 1981).

One possible explanation for the low level of polymorphism found in Morocco might be the choice of enzyme systems used in this analysis. However, one population included in this study, Tamjout, has also showed very low values of allozyme variation in wide-range studies (BARBA et al., 2001; GONZÁLEZMARTínEZ et al., 2004). On the other hand, in North Africa (M'HiRIT, 1999) and particularly in Morocco (BENABID, 1985; M'HiRIT and MAGHNOUJ, 1994), the increase of population inhabiting the region has led to overexploitation and accelerated degradation of forest resources. The disappearance of many ecosystems and species in Morocco has recently become a major concern. The degradation of some existing forest stands has dramatically impoverished the genetic pools of several species. This situation has been extensively described and analyzed by several authors (e.g., Tomaselli, 1976; FAO, 1993; SKourI, 1994). Moreover, CAUVIN et al. (1997) identified two main causes eventually conducive to stand depletion of Moroccan maritime pine: (i) intensive littering and woodland grazing by cattle and (ii) difficulties in the natural regeneration of this species, in particular when cattle grazing is involved. Hence, a more feasible explanation of the low diversity level found in Moroccan populations of maritime pine is related to the reduction of effective population size due to human impact. Data related to maritime pine exploitation are inexistent. However, fifty years ago, it has been estimated that the forest covers in the Rif region 4.300 .000 ha wile too recently; it covers about 3.275.000 ha (Boudy, 1951; BEDHRI, 1992). Moreover, the annual rate of the deforestation in the period 1981-1990 in North Africa was of 114,000 ha (M'HIRIT, 1999). Actually, as shown in table 1, maritime pine population's size in Morocco varied from 270 to 20 ha.

Marginal populations comprising few individuals or severely harvested show a significant reduction in genetic variation and the loss of rare alleles (YEH and LAYTON, 1979; LAMY et al., 1999). Genetic drift has been widely reported as the main cause of the reduction of genetic variability in marginal or isolated populations of conifers (LEDIG and CONKLE, 1983; HAMRIK et al., 1992; FALLOUR et al., 1997). Genetic drift along with restricted gene flow might also explain the high differentiation found in Moroccan populations of maritime pine $(\theta=10.44 \%)$. Genetic differentiation in Morocco is within the upper limit reported in the literature for conifer species (average $F s t=$ $6.50 \%$ in genus Pinus; HAMrick et al., 1992). Peтiт et al. (1995) reported Fst values of around 16\% in six geographical origins of Pinus pinaster from the wide-range distribution. Regional genetic differentiation estimates in other ranges of the species varied from around $\theta=2 \%$ in Portugal (estimated both with allozymes and cpSSRs; RIBEIRO et al., 2001 and references therein), where population structure was eroded by extensive gene flow, to Gst $=7.7 \%$ in Spain (SALVADOR et al., 2000), where different glacial refugia and ancient isolation of populations have been described. High values of genetic differentiation have often been associated to populations located at the edge of their range or to depleted populations with low effective population sizes. For instance, an Fst value of $11.30 \%$ was found in Picea glauca populations located at its northern range limit (Tremblay et al., 1989).
The existence of a population genetic structure has a main role in adaptation to local environmental variation. A moderate geographical structure is present in Moroccan maritime pine. Three main groups of populations can be distinguished: (i) Mediterranean Coastal, (ii) Occidental Rif and Middle Atlas and (iii) High Atlas. Burban and Petit (2003) comparing cpDNA and mtDNA data suggested pollen flow across the straight of Gibraltar and the native status of Punta Cires population. Our results are consistent with this interpretation as Punta Cires is the only population that has a private allele and its contribution to total allelic richness is high $(3.17 \%$, due mostly to the divergence component). Populations from Rif (both Mediterranean Coastal and Occidental) are characterized by high levels of diversity and a significant inbreeding coefficient. Partial selfing or parental inbreeding due to low effective population size could explain the deficiency of heterozygotes found at most loci in the Rif region. A possible Wahlund effect due to differences in allele frequencies in the effective pollen pool of each tree within single populations or to gene flow among populations, including long-distance gene flow across the straits of Gibraltar, could also explain our results. However, inbreeding does not appear to be an important process leading to subpopulation structuring in maritime pine (DUREL et al., 1996). Populations from Middle Atlas are characterized by low levels of allelic richness and gene diversity (both at the number of polymorphic loci and expected heterozygosity). Talaghine (TAL) population consists of an isolated stand of reduced size (20 ha) growing at high altitude $(1840 \mathrm{~m})$, which could explain the low number of alleles found in this population (24). In the case of Zaouia Ifrane (ZI) a bias in diversity estimates is possible due to cones being harvested from only eight individual trees. The only population sampled from High Atlas (Sidi Meskour) maintains considerable levels of polymorphism and a number of alleles higher than average. Moreover, this is the only population with a significant contribution to total diversity based on the divergent component and should be considered for conservation programs.

In conclusion, this paper reflects high levels of differentiation among populations and a moderate level of geographic structure of maritime pine populations in Morocco using enzyme markers. Populations located at Middle Atlas have been frequently included in genetic surveys of this species (e.g., Tamjout). However, this region presented the lowest level of allelic richness and genetic diversity found in Morocco. In order to reduce sampling biases, we recommend completing these surveys with populations from the main geographic groups described in this study: Mediterranean Coastal, Occidental Rif, Middle Atlas and High Atlas. One of the goals of conservation genetics is to use the information provided by genetic markers to implement conservation policies. In the case of maritime pine in Morocco this is an urgent necessity as overexploitation of the forest and land speculation are active mechanisms currently deploying the genetic resources of this species. In this paper, we have identified some populations of high interest for conservation (e.g., Sidi Meskour) and provided basic data to be combined with ecological and socioeconomic information in implementing conservation programs for maritime pine in Morocco.

\section{Acknowledgements}

This work was supported in part by the International Foundation for Science (IFS), Stockholm, Sweden, grants D/3033-1. Santiago C. GonzÁlez-Martínez was funded by a Fulbright/ MECD scholarship at University of California, Davis, USA. Thanks are extended to P. C. GRANT who revised the English language. 


\section{References}

Baradat, P. and Marpeau, A. (1988): Le Pin maritime (Pinus pinaster Ait.). Biologie et génétique des terpènes pour la conaissance et l'amélioration de l'espèce. Université Bordeaux I, Bordeaux, France.

Barba, D., González-Martínez, S. C., Ribeiro, M. M., Agúndez, D., Salvador, L., AlíA1, R. and Gil, L. (2001): Variación genética de Pinus pinaster Ait.: aplicación a la identificación y caracterización del material forestal de reproducción (MFR). Actas del III Congreso Forestal Español, Tomo V: 263-269.

Barbéro, M., Loisel, R., Quézel, P., Richardson, D. M. and Romane, F. (1998): Pines of the Mediterranean Basin. Pp. 153-170. In: RICHARDSON, D. M. (ed.). Ecology and biogeography of Pinus. Cambridge University Press, Cambridge.

BEDHRI, M. M. (1992): La protection juridique de l'arbre dans le droit marocaine, Actes des Premières Journées de l'Arbre, Ed. Laboratoire d'Ecologie Végétale Fac. Sci. Semlalia Marrakech, pp. 11-13.

BENABID, A. (1985): Les écosystèmes forestiers et pré forestiers du Maroc: diversité, répartition biogéographique et problèmes posés par leur aménagement. Forêt Méditerranéenne. VII: 53-67.

Burban, C. and Petit, R. J. (2003): Phylogeography of maritime pine inferred with organelle markers having contrasted inheritance. Molecular Ecology 12: 1487-1495.

Boudy P. (1951): Economie Forestière Nord-Africaine, description forestière du Maroc, tome troisième, Edit. F. Moncho, pp. 249.

Carrión, J. S., Navarro, C., Navarro, J. and Munuera, M. (2000): The distribution of cluster pine (Pinus pinaster) in Spain as derived from palaeoecological data: relationships with phytosociological classification. The Holocene $\mathbf{1 0}$ 243-252.

Cauvin, B., Marien, J. N. and El-Yousfo, S. M. (1997): Protection, conservation et gestion des ressources génétiques forestiers au Maroc. Ann. Rech. For. Maroc. 178-195.

Cheliak, W. M. and Pitel, J. A. (1984): Techniques for starch gel electrophoresis of enzymes from forest tree species. Petawawa Nat. For. Inst., Can. For. Serv. Agric., Canada.

Conkle, M. T., Hodgskiss, P. D., Nunnally, L. B. and Hunter, S. C. (1982): Starch gel electrophoresis of conifer seeds: a laboratory manual. USDA-Forest Service Gen. Tech. Rep. PSW$64,18 \mathrm{pp}$

Destremau, D. X., Jolly, H. and Thari, T. (1976): Contribution à la connaissance des provenances de Pinus pinaster. Ann. Rech. For. Maroc. 16: 101-153.

Durel, C. E., Bertin, P. and Kremer, A. (1996): Relationship between inbreeding depression and inbreeding coefficent in maritime pine (Pinus pinaster Ait.). Theor. Appl. Genet. 92 347-356.

El-Alami, S. L., Sbay, H., Petit, R. J. and Ouasson, A. (1997): Contribution à l'étude de la variabilité de six provenances marocaines de Pin maritime (Pinus pinaster Ait.). Pp. 56-62. In: Actes du séminaire sur l'amélioration, la conservation et l'utilisation des ressources génétiques forestières marocaines. ENFI Salé, Maroc.

Fallour, D., FADY, B. and LefÈvre, F. (1997): Study on isoenzyme variation in Pinus pinea L.: Evidence for low polymorphism. Silvae Genetica 46: 201-207.

FAO (1993): Programme d'action forestier méditerranéen: Cadre de référence des plans d'action forestiers nationaux des pays méditerranéennes. Committee on Mediterranean Forestry Questions, Sylva Mediterranea, Rome, $81 \mathrm{pp}$.

González-Martínez, S. C., Agúndez, D., Alí́a, R., SAlvador, L. and GIL, L. (2001): Geographical variation of gene diversity of Pinus pinaster Ait in the Iberian Peninsula. Pp. 161-171. In: Schubert, R. and MÜller-Starck, G. (eds.). Genetic response of forest systems to changing environmental conditions. Kluwer Academic Press, Dordrecht.

GonzÁlez-Martínez, S. C., Mariette, S., Ribeiro, M. M., BurBan, C., Raffin, A., Chambel, M. R., Ribeiro, C. A. M., Aguiar, A., Plomion, C., Alía, R., Gil, L., Vendramin, G. G. and Kremer, A. (2004): Genetic resources in maritime pine
(Pinus pinaster Ait.): molecular and quantitative measures of genetic variation and differentiation among maternal lineages. Forest Ecology and Management (in press).

GotTLiEB, L. D. (1981): Electrophoresis evidence and plant populations. Prog. Phytochem. 7: 1-46.

HAMrick, J. L. and GoDT, M. J. (1990): Allozyme diversity in plant species. Pp. 43-63. In: Brown, A. H. D., CleGG, M. T., KAHLER, A. L. and Weir, B. S. (eds). Plant population genetics, breeding and genetic resources. Sinauer, Sunderland. Mass.

HAMrick, J. L., Linhart, Y. B. and Mitton, J. B. (1979): Relationship between life history characteristics and electrophoretically detectable genetic variation in plants. Ann. Rev. Ecol. Syst. 10: 173-200.

Hamrick, J. L., Godt, M. J. and Sherman-Broyles, S. L. (1992): Factors influencing levels of genetic diversity in woody plant species. New Forests 6: 95-124.

HARFOUCHE, A., BARADAT, P. and Kremer, A. (1995): Variabilité intraspécifique chez le pin maritime (Pinus pinaster Ait.) dans le sud-est de la France. I. Variabilité des populations autochtones et de l'ensemble de l'aire de l'espèce. Ann. Sci. For. 52: 307-328.

Harfouche, A., Bahrman, N., Baradat, P., Guyon, J. P., Petit, J. R. and Kremer, A. (2000): Provenance hybridization in a diallel mating scheme of maritime pine (Pinus pinaster Ait.). II. Heterosis. Can. J. For. Res. 30: 10-16.

Hulme, M. (1999): Global Warming. Progress in Physical Geography 23: 303-311.

HURLBERT, S. H. (1971): The non concept of species diversity: a critique and alternative parameters. Ecology 52: 577-586.

KEPHART, S. R. (1990): Starch gel electrophoresis of plant isozymes: a comparative analysis of techniques. Amer. J. Bot. 77: $693-712$

LAMY, S., BouchaRd, A. and Simon, J. P. (1999): Genetic structure, variability and mating system in eastern white cedar (Thuja occidentalis) populations of recent origin in an agricultural landscape in southern Québec. Can. J. For. Res. 29 $1383-1392$

Ledig, F. T. and Conkle, M. T. (1983): Gene diversity and genetic structure in a narrow endemic, Torrey pine. Evolution 37: 79-85.

Lewis, P. O., ZAYKIN, D. (2001): Genetic Data Analysis: Computer Program for the Analysis of Allelic Data, Version 1.0 (d16c). Free program distributed by the authors over the internet from: http://lewis.eeb.uconn.edu/lewishome/software.html.

Loveless, M. D. and HAMRICK, J. L. (1984): Ecological determinants of genetic structure in plant populations. Ann. Rev. Ecol. Syst. 15: 65-95.

M'HiRIT, O. (1999): Mediterranean forest: ecological space and economic and community wealth. Unasylva 197: 3-15.

M'Hirit, O. and MaghnouJ, M. (1994): Stratégie de conservation des ressources génétiques forestières au Maroc. Pp 123138 in: Les ressources phytogénétiques et développement durable. Actes Editions, Rabat, Maroc.

M'Hirit, O., Sbay, H., El-Alami, S. L. and Kerrouani, H. (1997): Bilan de la recherche en matière de génétique forestière au Maroc. Pp. 1-29. In: Actes du séminaire sur l'amélioration, la conservation et l'utilisation des ressources génétiques forestières marocaines. ENFI Salé, Maroc.

Müller-Starck, G., Baradat, P. and Bergmann, F. (1992): Genetic variation within European tree species. New Forest 6: $23-47$.

NEI, M. (1973): Analysis of gene diversity in subdivided populations. Proc. Natl. Acad. Sci. USA 70: 3321-3323.

Nei, M., Maruyama, T. and ChaKRABorty, R. (1975): The bottleneck effect and genetic variability in populations. Evolution 29: $1-10$.

Nevo, E. (1978): Genetic variation in natural populations: patterns and theory. Theor. Pop. Biol. 13: 123-177.

Nguyen-Queyrens, A., Derre, N., Lamant, A. and Seillac, P. (1995): Tolérance au chlorure de sodium et sélectivité $\mathrm{Na} / \mathrm{K}$ chez trois races géographiques de Pin maritime (Pinus pinaster Ait.). Ann. Sci. For. 52: 465-475. 
Petit, R. J., Bahrman, N. and BARAdat, P. (1995): Comparison of genetic differentiation in maritime pine (Pinus pinaster Ait.) estimated using isozyme, total protein and terpenic loci. Heredity 75: 382-389.

Petit, R. J., El-Mousadik, A. and Pons, O. (1998): Identifying populations for conservation on the basis of genetic markers. Conservation Biology 12: 844-855.

Raffin, A. (1999): Pin maritime. Pp. 50-51. In: Tessier dU Cross, E. (ed.). Conserver les ressources génétiques forestières en France. MAP-BRG, Commission des Ressources Génétiques Forestières, INRA-DIC, Paris.

RAYMOND, M. and RousseT, F. (1995): GENEPOP (version 1.2): Population genetics software for exact tests and ecumenicism. J. Hered. 86: 248-249.

Ribeiro, M. M., Plomion, C., Petit, R. J., Vendramin, G. G. and SzMIDT, A. C. (2001): Variation in chloroplast single-sequence repeats in Portuguese maritime pine (Pinus pinaster Ait.) Theor. Appl. Genet. 102: 97-103.

Rogers, D. L. and LEDIG, F. T. (eds.) (1996): The status of temperate North American Forest Genetic Resources. Report 16. University of California, Genetic Resources Conservation Program, Davis, California.

Rothe, G. M. (1994): Electrophoresis for enzymes: laboratory methods. Springer Verlag, Bertin-Heidelberg, 307 pp.

SAlvador, L., AlíA, R., AgúNDEZ, D. and GiL, L. (2000): Genetic variation and migration pathways of maritime pine (Pinus pinaster Ait.) in the Iberian Peninsula. Theor. Appl. Genet. 100: 89-95.
SAvolainen, O. (2000): Guidelines for gene conservation based on population genetics. Pp. 100-109. In: KrishNAPILLAY, B. et al. (eds.). Proceedings of the XXI IUFRO World Congress, Malaysian XXI IUFRO World Congress Organising Committee, Malaysia.

SkouRI, M. (1994): Les dégradations du milieu et les mesures de protection. CR Acad. Agri. Fran. 80: 49-82.

TOMASELLI, R. (1976): La dégradation du maquis méditerranéen. Pp. 34-75. In: Forêts et maquis méditerranéens: écologie, conservation et aménagements. Note Technique MAB 2. UNESCO, Paris.

Tremblay, M. and Simon, J. P. (1989): Genetic structure of populations of White spruce (Picea glauca) at its northern limit of distribution in nouveau-Québec. Can. J. For. Res. 19: 1371-1379.

WeIR, B. S. (1990): Genetic Data Analysis. Sinauer, Sunderland, MA

YeH, F. C. and LAYTon, C. (1979): The organization of genetic variability in central and marginal population of lodgepole pine (Pinus contorta ssp. latifolia). Can. J. Genet. Cytol. 21: 487-503.

Yeh, F. C., Yang, R.-C., Boyle, T., Ye, Z.-H. and MaO, J. X. (1997): POPGENE, the user-friendly shareware for population genetic analysis. Molecular Biology and Biotechnology Centre, University of Alberta, Canada.

\title{
Chloroplast DNA Variation in Some Representatives of the Asian, North American and Mediterranean Firs (Abies spp)
}

\author{
By A. KormutaK ${ }^{1 *}$, B. Vookova ${ }^{1)}$, B. ZiegenhaGen ${ }^{2)}$, H. Y. KwON $^{3)}$ and Y. P. HonG ${ }^{3)}$
}

(Received $30^{\text {th }}$ January 2004)

\begin{abstract}
Using PCR-RFLP analysis, a comparative study on the restriction site polymorphism within 8 genes and regions of the Abies chloroplast DNA has been conducted covering 15 Asian, 6 North American and 7 Mediterranean species. A variable degree of divergence was observed among individual species of a given region as well as between geographical groups. A group of the Mediterranean firs, consisting of closely related species, differed profoundly from both Asian and North American representatives. Although a higher level of restriction site variants was detected among the Asian firs, two thirds of them were allocated to the difference between $A$. mariesii and the other Asian firs. The North American species exhibited the highest level of polymorphism resulting in several subgroups on a cladogram. At the individual species level, the Asian species $A$. mariesii and the North American species A. lasiocarpa

\footnotetext{
1) Institute of Plant Genetics and Biotechnology, Slovak Academy of Sciences, Akademicka 2, P.O.Box 39A, SK-950 07 Nitra, Slovak Republic.

2) Philipps-Universität Marburg, Fachbereich Biologie, Naturschutzbiologie, Karl-von-Frish-Strasse, D-35032 Marburg, Germany.

$\left.{ }^{3}\right)$ Korea Forest Research Institute, Dpt. of Forest Genetic Resources, Genetic Resources Division, 44-3 Omokchun-dong, Kwonsun-ku, Suwon 441-350, Kyunggi-do, Republic of Korea.

*) Corresponding author (e-mail: nrgrkorm@savba.savba.sk)
}

diverged conspicuously from their counterparts in their respective regions. The results of restriction site polymorphism analysis are discussed with ragard to crossability and taxonomic status of individual species.

Key words: Abies, chloroplast DNA, restriction site variation, relationships, species differentiation.

\section{Introduction}

The genus Abies is a prominent representative of the Pinaceae in Northern Hemisphere. According to the taxonomic account by LIU (1971) the genus comprises 39 species, 23 varieties and 8 natural hybrids between sympatric species growing in different parts of the world. A more recent classification FARJON and RUSHFORTH (1989) proposed the existence of as many as 49 species, 23 varieties and 1 natural hybrid in Abies.

Based on the karyological evidence of SAx and SAX (1933) and the crossability data by ROHMEDER and EISENHUT (1961), a close genetic relationship within the genus has been suggested (Kiellander, 1962; KlaeHN and Winieski, 1962). Extensive experiments with artificial cross-pollination of Abies spp. have however only partially validated this conclusion. A high degree of mutual crossability has been proved unequivocally only among the Mediterranean firs (GREGUSS, 1984; KoRMUTAK, 